\title{
Discussion and Analysis of Countermeasures to Strengthen the Management Effect of Graduation Internship from Auditing and Reviewing Perspectives
}

\author{
Ying ZHANG \\ Department of Teaching Affairs, Jilin Agricultural University,Changchun, 130118,China \\ email: jlauzy@126.com
}

\begin{abstract}
Keywords: Graduation Internship; Management System; Process Management; Goal Management
\end{abstract}

\begin{abstract}
Under the new situation that higher education is developing from massification to popularization, undergraduate teaching assessment and evaluation conducted by the Ministry of Education is an important measure to evaluate, supervise, guarantee and improve undergraduate teaching quality. This paper analyzes the problems in the management of graduation internship from auditing and reviewing perspectives and puts forward the countermeasure to strengthen the management of graduation internship to realize the goal of guaranteeing and improve the quality of graduation internship.
\end{abstract}

\section{Introduction}

A new round of higher school undergraduate teaching quality evaluation conducted by the Ministry of Education focuses on "assessment and evaluation", which emphasizes autonomy and diversification of higher schools. It stresses that schools "use their own ruler to measure themselves" and strengthen system establishment of internal quality guarantee. Higher schools should set target in accordance with their situation and evaluate the teaching quality, student learning effect according to the set target and evaluate the expected results under school-running objectives. And then publicize the evaluation report and accept supervision from all sections of the society.

Graduation internship, an indispensable part of higher school teaching system and an irreplaceable section, is the continuation of school teaching, link between employment and the transition from study to employment for students in the process of internship. Graduation internship combines basic theory, basic knowledge and basic skills and be integrated and finally achieve a true understanding and mastery of them. It takes production site, the best augmented reality and effect, as the basis combined with eyes, mouth, hands and brain and it is also the best training exercise of the exchanges between teachers and students. We hold the attitude of being responsible for the school and students and the principles of "promote reform, establishment and management with evaluation, a combination of evaluation and establishment with the emphasis on establishment". We are determined to strengthen the management of graduation internship with the goal of comprehensively improve teaching quality and finally successfully passed undergraduate teaching assessment and evaluation[1].

\section{Problems occurring in the management of graduation internship}

Graduation internship, as an important section in the cultivation of higher school talents, is indispensable. However, with the advance of science and technology and social reform and development, internship of university students, especially graduation internship faces more and more difficulties and problems. It also leads to people's doubt and contempt for the function of graduation internship. Therefore, there also exist many problems in the management of graduation internship. 
Discount of graduation internship.

Teachers, students or management department, more or less, has this tendency. It is demonstrated, in one respect, that they are unclear about the significance of the section of graduation internship. The second respect is the lack of emphasis on guiding internship and the adoption of attitude of not interfering. Especially when there are many scattered internship, the instructor is likely to catch one and lose another or even let them follow their own inclination. The third respect is management department's lack of emphasis of graduation internship and the scare lack of fund investment. The fourth respect is that students lack the awareness of the function of graduation internship. Some students fail to realize that graduation internship is a valuable experience and it will generate relatively significant impact for work and behavior afterwards[2].

Unsound management system.

Internship, an important section of teaching, is greatly different from class teaching and must be treated differently. From current status, most of the higher schools lack regulative documents on internship. Even though some schools have one, but it is rather old version and fails to put forward new management methods in accordance with the development of situation and the content of internship and changes of forms. This makes student internship lacks a necessary basis.

It is difficult to put management in place.

Under current social status, methods of internship present diversified tendency. Diversified internship models offer graduation internship of students more choices but bring problems for management. Under the current status of continual expansion of enrollment of higher schools, lack of teachers in higher schools is very prevalent phenomenon and dispatched graduation instructors also relatively decrease. On the other hands, the graduation internship classes are increasing and the time is relatively concentrated. If students do the internship scattered and in rather scattered locations, the work amount of the instructors will be heavy. In this situation, it is very difficult to put management in place if originally there is lack of emphasis of internship. If there lacks strict and regulative requirements, schools lack monitoring system to internship of all majors and colleges lack supervision of the instructors, the circumstances of muddling through and let things follow their inclination will inevitably occur[3].

It is precisely because of the lack of emphasis, unsound management system and inadequate management that phenomena, such as part of graduation internships going through or muddling through the motions, exist, which will inevitably affect the quality of the internship. Therefore, we must first start from strengthening awareness, perfecting and improving internship management in order to guarantee and improve teaching quality of graduation internship.

\section{Countermeasure to strengthen the management of graduation internship}

Strengthening standard management and clarifying graduation internship goals.Formulate uniformly requested internship outline, plan and instruction for all majors and clarify the internship goal requirement students should reach during the internship so that they can achieve real experience, feel real responsibility and receive comprehensive training. Through internship, students can combine theory and practice, consolidate and improve their major knowledge and study for the purpose of application. And also enrich and broaden their knowledge and cultivate their spirit of enduring hardship and stand hard work as well as the spirit of industrious and hard-working.

Strengthening standard management and formulating graduation internship plan.Under the current condition, in order to achieve the best internship effect, pragmatics must be demonstrated when formulating internship plan and the key point, foundation, process and details must be focused and graduation internship system as well as management standards and regulations must be established and improved. Choose the best internship unit and implement 3 stages plans of preparation before internship, internship out of school and internship summary after back to school. Regulative plan standards must be formulated from internship time, unit, and division into groups, instructor and content[4].

Strengthening standard management and implementing graduation internship 
requirements.After the formulation of graduation internship, systematic implementation is the key. First, earnestly organize and mobilize before internship. Internship lead teacher will tell clearly the internship content, methods, and discipline and assessment methods to the students so as to rectify students' internship attitude and clarify the purpose and importance of internship. Second is to summarize some practical experience during the past internship in accordance with internship content and methods so as that students can understand the content before internship and get in the zone of internship. At last, intern students should finish the writing of internship journals and reports, including purpose content, process, result, summary and experience of internship as the standard basis for filling the graduation internship evaluation form and assessment internship grades.

Strengthening standard management and elaborating the management of graduation internship.With the deeper cooperation between higher schools and enterprises, management models of graduation internship need to be more close to the practical production requirements of enterprises. First of all, intern students and teachers should strictly follow relevant systems and technological confidentiality rules and modestly learn from the workers and show civilization and etiquettes. Next discipline is a basic guarantee to complete the internship tasks and strictly abide by the relevant regulations of the school during internship and carry out internship according to graduation internship outlines and plans.

Management of graduation internship requires correct guidance. Instructors should unconsciously influence students' understanding and interest for internship with their behaviors and earnest and rigorous working attitude. Trust students and find some typical examples during the internship by observing in order to be used as the source material to educate students. Comprehensively evaluate and break traditional method of only assessing internship at the production site. Preparation for internship and the completion of internship summary are all taken as the assessment scope and conduct comprehensive assessment from "attitude of internship, behavior at the production site, observing and raising questions, thinking and understanding after linking theory and reality, behavior at the symposium, details of the internship diary and the logic and format of internship report."

Strengthening standard management and perfecting the guidance of graduation internship.Internship instructors are responsible for the organization, guidance, management of students' internship and their work goes through the whole process of it. Bringing the functions of internship instructors to play is the necessary condition to improve students' internship gains.

Teachers are the key to the implementation of internship plan. When finishing internship guidance, the quality standard of internship guidance should also be regulated. (1) Emphasize the responsibility of the instructors. They should actively carry out various works during the internship, pass practical skills, understand students' basis information and give proper advice and reminder for future development. (2) Instructors should not only instruct from theory but also offer help in practice. They should earnestly instruct at the production site to help students to broaden and enrich knowledge, increase and improve capability and lay certain foundation for entering the society. (3) Pay attention to students' ability to analyze and think about problems during the internship and attach importance to the cultivation of students' project practical abilities and innovative thinking abilities. Make students feel they are personally on the production scene and carry out professional ethic education to the students. (4) Do well in summarizing the work, analyze objectively the reflection and advice from the internship units and earnestly write internship work report in order to accumulate experience for next internship and form benign circle[5].

\section{Conclusion}

In brief, graduation internship is an important teaching practice section of cultivating students' abilities. Different higher schools should establish corresponding quality guarantee system and standard according to their own conditions, set targets and conduct assessments to internship quality, expected results of students' internship effect on campus and outside campus. Only by constant practical research can we form effective mechanism for the management of graduation internship. 


\section{References}

[1] Hu Ruiping. Strengthen the management of graduation practice and strengthen the effect of graduation practice $[\mathrm{J}]$. China Management Informationization,2013(18).

[2] Wei Chonghong. Exploration and research on the practice management measures of College Students. [J]. Chinese off Campus Education,2013(3).

[3] Liu Hongzhan. Discussion on how to improve the practice management[J]. China Education Innovation Herald,2011(35).

[4] Jiang Xin. Reflections on strengthening the management of students' professional practice in undergraduate colleges and Universities[J]. Journal of Jilin Business and Technology College,2015(6).

[5] Chen Cuiwei. Optimizing practice management paradigm helps cultivate professional teachers[J]. Journal of Wuyi University,2013(3). 